\title{
A new species of the genus Glaesotropis Gratshev and Zherikhin, 1995 (Coleoptera, Anthribidae) from Rovno amber
}

\author{
Andrei A. Legalov ${ }^{1,2}$, Vitaliy Y. Nazarenko ${ }^{3}$, and Evgeny E. Perkovsky ${ }^{3,4}$ \\ ${ }^{1}$ Institute of Systematics and Ecology of Animals, Siberian Branch, Russian Academy of Sciences, \\ Frunze Street 11, Novosibirsk 630091, Russia \\ ${ }^{2}$ Altai State University, Lenina, 61, Barnaul 656049, Russia \\ ${ }^{3}$ Department of Entomology and Collection Management, I. I. Schmalhausen Institute of Zoology, National Academy of \\ Sciences of Ukraine, B. Khmel'nyts'koho 15, Kiev 01601, Ukraine \\ ${ }^{4}$ A. A. Borissiak Paleontological Institute of the Russian Academy of Sciences, Moscow, Russia
}

Correspondence: Andrei A. Legalov (fossilweevils@gmail.com)

Received: 25 October 2020 - Revised: 20 November 2020 - Accepted: 24 November 2020 - Published: 14 January 2021

\begin{abstract}
A new fungus weevil, Glaesotropis (Electranthribus) rohdendorfi sp. nov. (Coleoptera: Anthribidae), is described from Priabonian Rovno amber. It is similar to $G$. (E.) zherikhini (Legalov, 2013a) but differs in the transverse carina extending to the scutellum, shorter antennomere 2, wider antennal club, more convex eyes, and larger body size. It is the first record of the subgenus Electranthribus Legalov, 2013a from Rovno amber, the first named beetle from the Olevsk amber locality, and the sixth amber species reported from the Zhytomyr region. An aggregation of glaesacarid mites Glaesacarus rhombeus (Koch and Berendt, 1854) as a syninclusion with the fungus weevil is reported for the first time (41 specimens); the possibility of the glaesacarids feeding on fungi is discussed.
\end{abstract}

\section{Introduction}

The family Anthribidae (fungus weevils) is a small group of quite primitive Curculionoidea with more than 3800 extant species (Rheinheimer, 2004). It has five subfamilies (Legalov, 2015, 2018a). Subfamilies Juranthribinae and Protoscelinae are extinct, known from the Middle-Late Jurassic of Karatau, Kazakhstan (Legalov, 2011b, 2013b; Medvedev, 1968). Compression fossils of the subfamily Urodontinae have been reported from Priabonian (late Eocene)Chattian (late Oligocene) of Europe (Hieke and Pietrzeniuk, 1984; Legalov, 2020c). Extinct taxa of the subfamily Choraginae have been described from the Early Cretaceous of Spain
(Soriano et al., 2006), the Eocene of North America (Scudder, 1890), and the Eocene (Legalov et al., 2018) and latest Oligocene of Europe (Heyden and Heyden, 1866). The subfamily Anthribinae is well presented in the fossil record. The oldest forms are known from the mid-Cretaceous (Zherikhin, 1993; Legalov et al., 2019b, and references therein) and the Turonian-Coniacian (Legalov, 2020b) of the Russian Far East. Thirteen species are described from the Ypresian (early Eocene) of the USA and France (Scudder, 1893; Legalov et al., 2019a; Legalov, 2018b, 2020c) and 14 from Priabonian ambers (Voss, 1953; Zherikhin, 1971; Gratshev and Zherikhin, 1995; Gratshev and Perkovsky, 2008; Legalov, 2012, 2013a, 2015, 2020a). The subfamily has been found in Miocene Mexican and Dominican ambers (Poinar and Legalov, 2016; Legalov et al., 2019b).

Two species of fungus weevils are known from Priabonian Rovno amber (Gratshev and Perkovsky, 2008; Legalov et al., 2018). Here, we describe a third anthribid species from this amber. Seventeen curculionoid species are reported from Rovno amber, all unknown from Baltic amber; besides Anthribidae, these include one species of Rhynchitidae (Bukejs and Legalov, 2019b), one of Brentidae (Bukejs and Legalov, 2020), nine of Curculionidae (Nazarenko and Perkovsky, 2009, 2016; Nazarenko et al., 2011; Bukejs and Legalov, 2019a; Legalov et al., 2019c), and three of Scolytidae (Petrov and Perkovsky, 2008, 2018). Half of the Rovno amber curculionoid genera (7 of 14) are unknown from Baltic amber (Legalov, 2020c). 
Both earlier described species were collected in the Rovno region, one in Klesov and the second in Klesov or Dubrovytsya (Jałoszyński and Perkovsky, 2016, fig. 37). The new anthribid is the first amber beetle described from the Zhytomyr region; only two new genera and four new species of gall midges (Fedotova and Perkovsky, 2015, 2017) and one caddisfly (Perkovsky, 2017) were determined to the species level from Zhytomyr region localities (Olevsk and Gulyanka) until now. The biota from these localities is quite important, as confidently dated plant fossils are also known from the same area (Sokoloff et al., 2018, and references therein).

\section{Material and methods}

Like the famous Baltic amber, Priabonian Rovno amber is succinite (Perkovsky et al., 2010; Bellés and Perkovsky, 2016). Its botanical origin is highly controversial (Seyfullah et al., 2018).

The amber sample that we examined is deposited in the Schmalhausen Institute of Zoology of the National Academy of Sciences of Ukraine, Kiev (SIZK), amber collection. It was cut from a clear piece of amber OL-146 (size $68 \times$ $26 \times 26 \mathrm{~mm}$; weight before primary treatment $21.2 \mathrm{~g}$ ). The photographs were taken with a Leica M165C microscope equipped with Leica DFC450C digital camera and Leica Z16 APO microscope equipped with Leica DFC 450 camera and processed by LAS Core software.

Morphological terminology follows Lawrence et al. (2010).

This article is registered in ZooBank (http: //www.zoobank.org, last access: 20 November 2020) under LSID urn:lsid:zoobank.org:pub:5A5C3FF3-338240F9-9864-AFFBFFD63D17.

\section{Systematic palaeontology}

Order Coleoptera Linnaeus, 1758

Suborder Polyphaga Emery, 1886

Superfamily Curculionoidea Latreille, 1802

Family Anthribidae Billberg, 1820

Subfamily Anthribinae Billberg, 1820

Tribe Zygaenodini Lacordaire, 1865

Genus Glaesotropis Gratshev and Zherikhin, 1995

Subgenus Electranthribus Legalov, 2013a

Glaesotropis (Electranthribus) rohdendorfi sp. nov. urn:lsid:zoobank.org:act:67C876B0-5DEB-481A83B3-9F6889BD4267

Figs. 1-3.

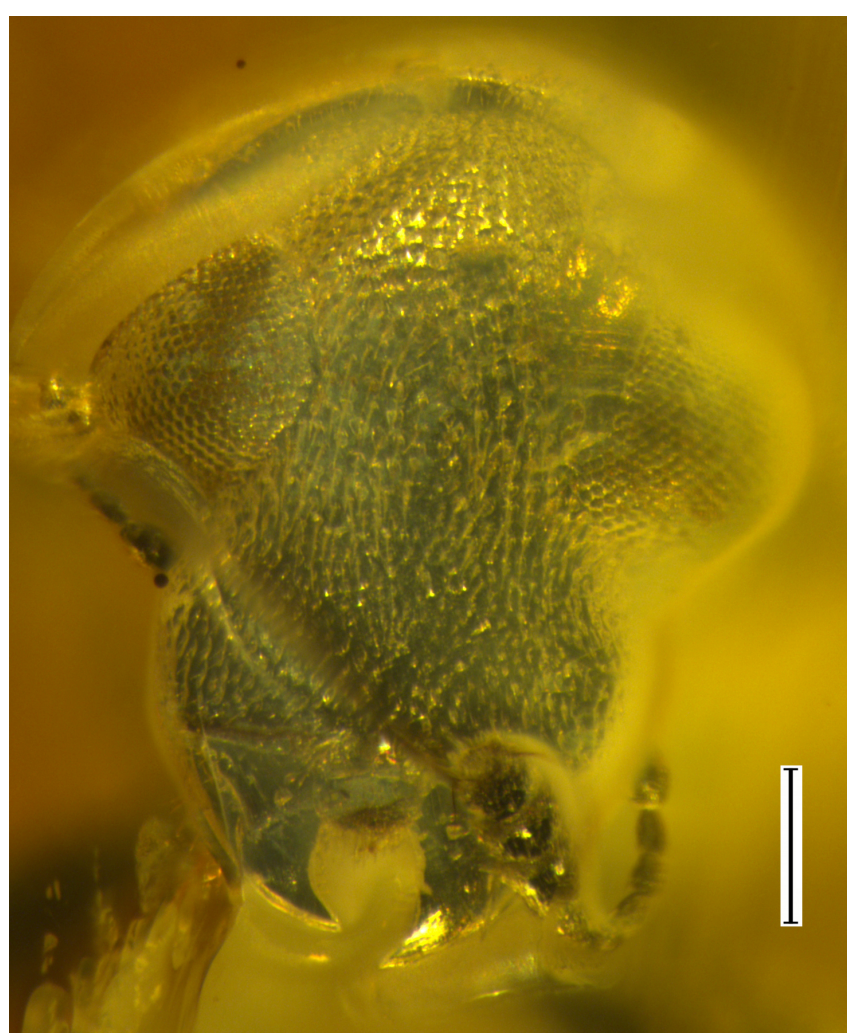

Figure 1. Glaesotropis rohdendorfi sp. nov., holotype. SIZK OL269 , rostrum and head, dorsally. Scale bar $0.2 \mathrm{~mm}$.

\section{Etymology}

It is named in honour of the great palaeoentomologist Boris B. Rohdendorf, who determined the first Zhytomyr inclusion to family level (Rhagionidae).

\section{Type material}

Holotype SIZK OL-269. The amber sample with inclusion is deposited in the amber collection of Schmalhausen Institute of Zoology of the National Academy of Sciences of Ukraine, Kiev (SIZK). Syninclusions (samples SIZK OL-259 - SIZK OL-269): numerous stellate hairs, 2 dipterans (Chironomidae and Sciaroidea), and 44 mites. Mites represented by 41 Glaesacarus rhombeus (Koch and Berendt, 1854), 2 Oribatei, and undetermined mite.

Type stratum: Rovno amber, Priabonian

Type locality: Olevsk, Zhytomyr region, Ukraine

\section{Description}

Size: body length (without rostrum) $3.05 \mathrm{~mm}$, rostrum length $0.46 \mathrm{~mm}$.

Body: black, covered with sparse, light appressed hairs.

Head: rostrum short, almost straight, 0.6 times as long as pronotum, 0.55 times as long as wide at apex, 0.5 times 
as long as wide in middle, 0.53 times as long as wide at base, densely punctate, flattened, without middle carina. Mandibles large. Labrum free. Forehead 0.7 times as long as wide at rostrum base, 2.0 times as wide as longitudinal eye diameter, weakly flattened, densely punctate. Eyes large, rounded, convex, finely faceted. Temples very short. Vertex slightly convex, densely punctate. Antennae straight and long, inserted laterally in basal third of rostrum. Scape 1.9 times as long as wide. Antennomeres: (2)-(8) conical; 2-1.4 times as long as wide, 1.2 times as long as and 1.6 times as wide as scape; (3) 1.6 times as long as wide, 0.8 times as long as and 0.7 times as narrow as antennomere 2; (4)(6) subequal in wide; (4) 1.4 times as long as wide, 0.8 times as long as and 0.8 times as narrow as antennomere 3 ; (5) 1.3 times as long as wide, slightly narrower than antennomere 4; (6) 1.5 times as long as wide, 1.1 times as long as antennomere 5; (7) 1.3 times as long as wide, 0.9 times as long as and slightly wider than antennomere 6; (8) 1.2 times as long as wide, 0.9 times as long as and slightly wider than antennomere 7; antennal club distinct, loose, 0.6 times as long as antennomeres 2-8 combined; (9) 0.7 times as long as wide, 1.3 times as long as and 2.4 times as wide as antennomere 8; (10) 0.5 times as long as wide, 0.8 times as long as and 1.1 times as wide as antennomere 9; (11) 1.1 times as long as wide, 1.8 times as long as and 0.8 times as narrow as antennomere 10 .

Pronotum: weakly bell-shaped, width subequal at apex, 0.9 times as long as wide in middle and at base, coarsely punctate, slightly convex. Transverse carina subbasal, angularly extended to scutellum. Lateral carina absent. Posterior angular carina complete. Pronotal declivity about 0.1 times as long as pronotum.

Mesonotum: scutellum small, almost triangular.

Elytra: quite wide, 1.9 times as long as pronotum, 1.3 times as long as wide at base and in apical quarter, 1.1 times as long as wide in middle. Humeri weakly smoothed. Striae shallow. Interstriae convex, finely punctate.

Thorax: prosternum coarsely punctate. Precoxal part of prosternum equal to procoxa length. Procoxal cavities rounded, separated. Postcoxal part of prosternum 0.7 times as long as procoxa length. Mesocoxal cavities rounded and separated. Metaventrite 1.1 times as long as length of mesocoxa, flattened, densely punctate. Metepisternum 5.0 times as long as wide in middle. Metacoxal cavities dilated.

Abdomen: convex, weakly flattened in middle. Abdominal ventrites 1-4 fused. Ventrite 1, 0.7 times as long as metacoxae. Ventrite 2, 1.4 times as long as ventrite 1. Ventrite 3, 1.1 times as long as ventrite 2 . Ventrite 4, 0.8 times as long as ventrite 3 . Ventrite 5, 1.5 times as long as ventrite 4. Pygidium exposed.

Legs: long. Procoxae spherical. Femora clavate, without tooth. Profemora 2.4 times as long as wide in middle. Mesofemora 2.8 times as long as wide. Metafemora 3.0 times as long as wide. Tibiae almost straight, weakly flattened, without mucro. Protibia 5.6 times as long as wide in mid-

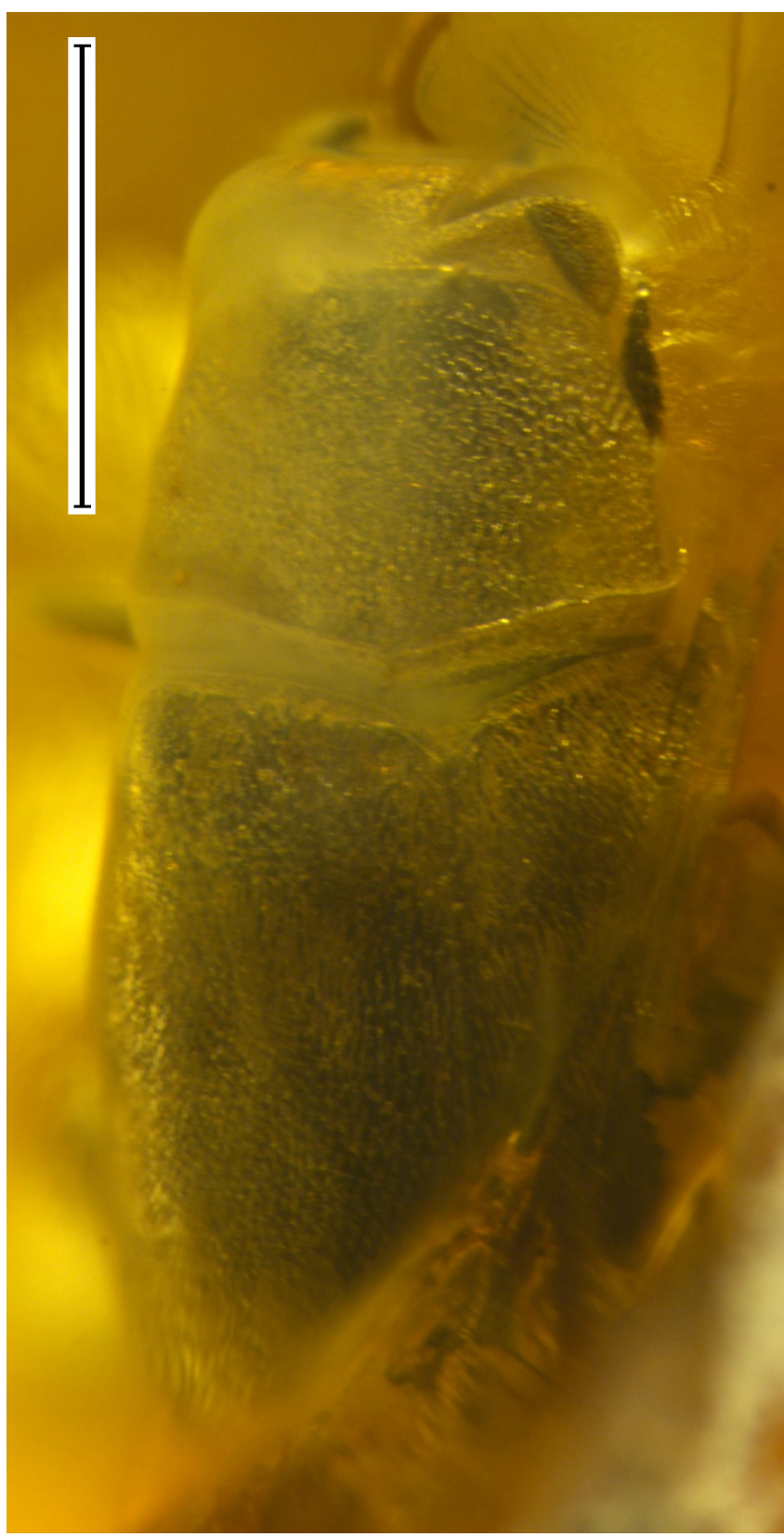

Figure 2. Glaesotropis rohdendorfi sp. nov., holotype. SIZK OL269 , body, dorsally. Scale bar $1.0 \mathrm{~mm}$.

dle. Mesotibia about 6.3 times as long as wide in middle. Metatibia 5.3 times as long as wide in middle. Tarsi elongate, shorter than tibiae, with pulvilli ventrally. Tarsomeres: (1) elongate, conical; (2) wide, conical, bilobed, covers base of tarsomere 3; (3) bilobed, narrower than second; (5) elongate. Claws large, diverging, free, with teeth. Protarsomeres:

(1) 2.1 times as long as wide; (2) 1.4 times as long as wide, 0.9 times as long as and 1.3 times as wide as tarsomere 1;

(3) 1.2 times as long as wide, 0.5 times as long as and 0.6 


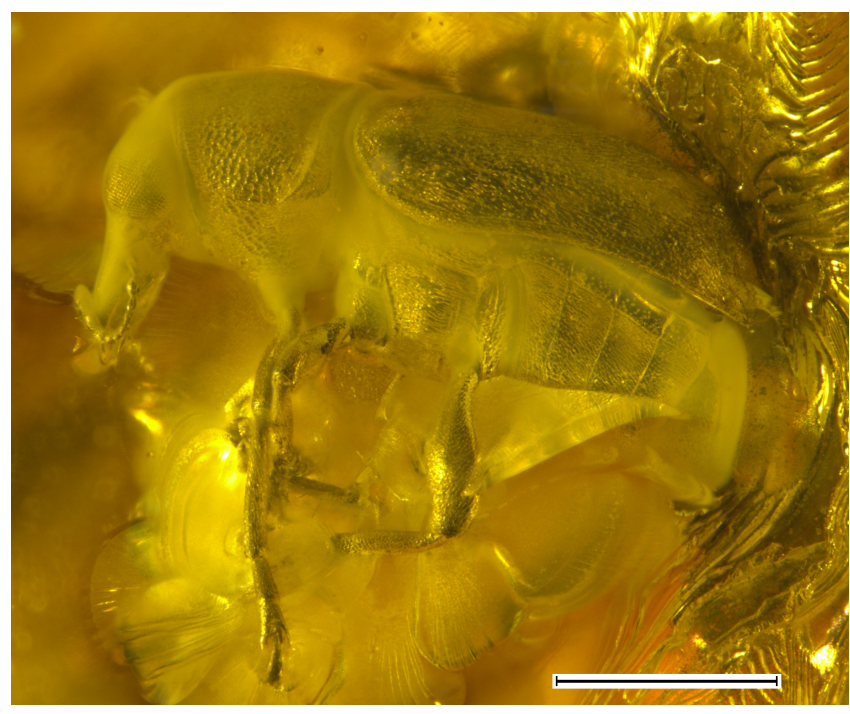

Figure 3. Glaesotropis rohdendorfi sp. nov., holotype. SIZK OL269 , body, laterally. Scale bar $1.0 \mathrm{~mm}$.

times as narrow as tarsomere 2; (5) 3.5 times as long as wide, 2.7 times as long as and 0.9 times as narrow as tarsomere 3 .

\section{Comparison}

The new species is most similar to the largest species of the subgenus, Glaesotropis (Electranthribus) zherikhini (Legalov, 2013a) by their shared complete posterior angular carinula and precoxal part of prosternum subequal in length of the procoxa. It differs in its transverse carina extended to the scutellum, the shorter antennomere 2 (1.3 times as long as antennomere 3 ), wider antennal club (length 2.0 times maximum width), more convex eyes, and its larger body size. The species differs from G. (Glaesotropis) diadiasashai Gratshev and Perkovsky, 2008 (Fig. 4) from Rovno amber by its smaller body size, antennomere 3 distinctly narrower and shorter than antennomere 2 , shorter rostrum, and the transverse carina extended to the scutellum.

\section{Remarks}

Tarsomere 2 covers the base of tarsomere 3, the labrum is free, the pygidium is exposed, the antennae are straight, and the tibiae lack spurs, suggesting placement of the new species in the family Anthribidae. The antennae are inserted laterally, abdominal ventrites 1-4 are fused and the elytra striate suggest that it belongs to the subfamily Anthribinae. Placement of this species in the tribe Zygaenodini is based on the rostrum being shorter than its width, and the eyes being finely faceted. Its strongly convex eyes, wide antennal club, and transverse carina quite distant from base of the pronotum indicate that the new species belongs to the genus Glaesotropis. It belongs to the subgenus Electranthribus based on its forehead being wider than its longitudinal eye diameter, and an-

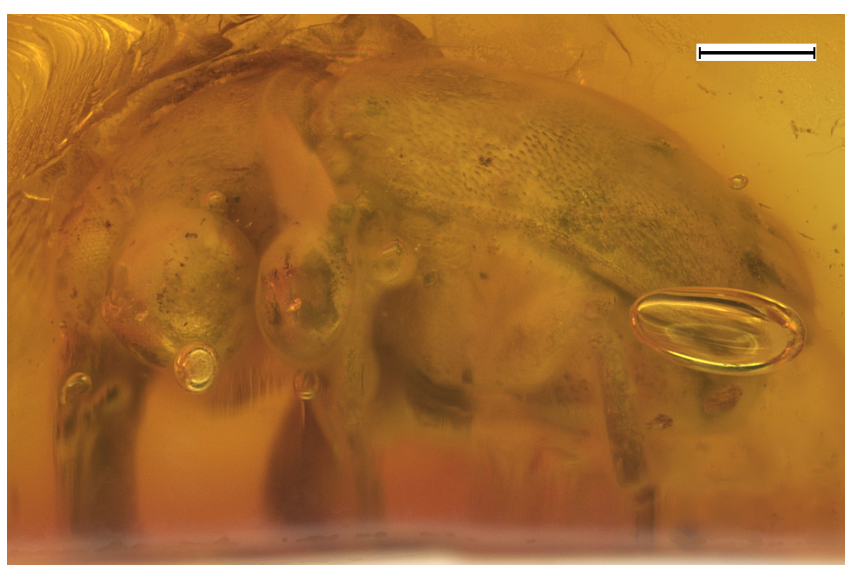

Figure 4. Glaesotropis diadiasashai Gratshev and Perkovsky, 2008, holotype. SIZK UA-2223, body, laterally. Scale bar $0.5 \mathrm{~mm}$.

tennomere 3 being distinctly narrower and shorter than antennomere 2.

\section{Discussion}

Glaesotropis is an extinct genus of the tribe Zygaenodini, known only from Priabonian amber (Legalov, 2020a, c). They have not been found either in Ypresian amber or as compression fossils. For example, they are absent from the diverse Priabonian weevil fauna of Florissant, Colorado, USA. The genus has 3 subgenera and 11 species. The subgenus Pseudoglaesotropis Legalov, 2012 differs by its narrow forehead. It is represented by two species, only known from Baltic amber. The subgenera Glaesotropis sensu stricto and Electranthribus Legalov, 2013a are distinguished by the shape of antennomeres 2 and 3. Five species are known from the nominative subgenus: four from Baltic amber and one from Rovno amber. $G$. (G.) minor Gratshev and Zherikhin, 1995 is one of the most common Baltic amber weevils.

The subgenus Electranthribus is represented by three species in Baltic amber. The new Rovno amber species is similar to $G$. (E.) zherikhini but differs by characters indicated in the comparison, above. Thus, no common species of this genus are reported from both ambers. This is not surprising, as only $13 \%$ from Rovno amber beetles species are known from Baltic amber (Kupryjanowicz et al., 2021, and references therein).

The genus Glaesotropis is close to the extant Autotropis Jordan, 1924 but differs in its strongly convex eyes, wide antennal club, and transverse carina quite distant from base of the pronotum (Gratshev and Zherikhin, 1995). Autotropis is distributed in East Asia (six species), Southeast Asia (three species) and South Asia (four species) (Rheinheimer, 2004). Species of this genus develop on Zelkova (Morimoto, 1981) and Carpinus (Legalov, 2011a); both are known from the Eocene of Europe (Eckfeld, Germany); interestingly, Zelkova 
can be infested by stylotermitids (Liang et al., 2017), which were recently described from Rovno amber (Perkovsky and Vasilenko, 2020). An assumption can also be made about the trophic links of Glaesotropis species with deciduous trees. The mite Glaesacarus rhombeus is very common in all Priabonian ambers (Perkovsky et al., 2007, 2012), but its ecology is unknown, although feeding on bark and bracket fungi was considered as one possibility (Sidorchuk and Klimov, 2011). The species constitutes $27 \%$ of all mites in Rovno amber (our unpublished data), which may be explained by large aggregations in some pieces. All Zygaenodini develop in the bark or wood of gymnosperms and angiosperms attacked by fungi. Imagos often feed on fungal spores and fruiting bodies, in particular soft polypores, ascomycetes, and jelly fungi (Auricularia) on dried tree trunks and branches. If the feeding habits of Glaesacarus rhombeus are similar, this would explain the peculiarities of their distribution in European Priabonian amber.

Data availability. All material included in this paper is deposited in the Schmalhausen Institute of Zoology, National Academy of Sciences of Ukraine, Kiev.

Author contributions. VYN and EEP produced the photos. AAL, VYN, and EEP prepared the paper and contributed to the editing.

Competing interests. The authors declare that they have no conflict of interest.

Acknowledgements. The authors thank Alexandr G. Ponomarenko, Alexandr P. Rasnitsyn, and Irina D. Sukatsheva (Borissiak Paleontological Institute RAS, Russia: Moscow), Albert Allen (USA: Boise), Viktor A. Gusakov (Russia: Moscow), Friedhelm Eichmann (Germany: Hannover), Nikolai V. Martynovich (Museum of the World Ocean, Russia: Kaliningrad), and Andranik R. Manukyan and Anna V. Smirnova (Kaliningrad Regional Amber Museum, Russia: Kaliningrad), for providing comparative material of genus Glaesotropis, Aleksandr V. Martynov (SIZK) for multifocal photos of $G$. diadiasashai, Anatoly P. Vlaskin (SIZK) for cutting and polishing the piece, Nikolai R. Khomich (Rovno) for help with obtaining the material, Bruce Archibald (Simon Fraser University, Burnaby, Canada) for editing of the English, George O. Poinar Jr. (USA: Corvallis), and Andris Bukejs (Latvia: Daugavpils), for the valuable comments.

Review statement. This paper was edited by Rene Hoffmann and reviewed by Andris Bukejs and one anonymous referee.

\section{References}

Bellés, X. and Perkovsky, E. E.: New data on the genus Sucinoptinus (Coleoptera, Ptinidae) from Rovno amber, Vestn. Zool., 50, 17-22, 2016.

Billberg, G. J.: Enumeratio insectorum in museo Gust. Joh. Billberg, Typis Gadelianis, Stockholm, Sweden, 1820.

Bukejs, A. and Legalov, A. A.: First record of the tribe Naupactini (Coleoptera: Curculionidae) in Rovno amber, Foss. Rec., 22, 25 30, https://doi.org/10.5194/fr-22-25-2019, 2019a.

Bukejs, A. and Legalov, A. A.: The first record of Rhynchitidae (Coleoptera) from Rovno amber, Entomol. Fennica, 30, 168172, https://doi.org/10.33338/ef.87173, 2019b.

Bukejs, A. and Legalov, A. A.: The first record of Brentidae (Coleoptera) in Eocene Rovno amber with description of a new fossil species of Toxorhynchus Scudder, 1893, Foss. Rec., 23, 169-177, https://doi.org/10.5194/fr-23-169-2020, 2020.

Emery, C.: Über Phylogenie und Systematik der Insekten, Biol. Centralblatt, 5, 648-656, 1886.

Fedotova, Z. A. and Perkovsky, E. E.: New gall midges (Diptera, Cecidomyiidae, Stomatosematidi, Brachineuridi) from the Late Eocene amber of Gulyanka (Zhitomir Region, Ukraine), Paleontol. J., 49, 270-278, 2015.

Fedotova, Z. A. and Perkovsky, E. E.: New genus and species of gall midges (Diptera, Cecidomyiidae, Porricondylinae, Holoneurini) from the Late Eocene amber of Olevsk (Zhitomir Region, Ukraine), Vestn. Zool., 51, 23-30, 2017.

Gratshev, V. G. and Perkovsky, E. E.: New species of the genus Glaesotropis (Insecta: Coleoptera: Anthribidae) from Rovno amber, Paleontol. J., 42, 60-63, 2008.

Gratshev, V. G. and Zherikhin, V. V.: A new anthribid genus from the Baltic amber (Insecta: Coleoptera: Anthribidae), Mitt. Geol.Paläontol. Instit. Univ. Hamburg, 78, 149-157, 1995.

Heyden, C. and Heyden, L.: Käfer und Polypen aus der Braunkohle des Siebengebirges, Palaeontographica, 15, 131-156, 1866.

Hieke, F. and Pietrzeniuk, E.: Die Bernstein-Käfer des Museums für Naturkunde, Berlin (Insecta, Coleoptera), Mitt. Zoolog. Mus. Berlin, 60, 297-326, 1984.

Jałoszyński, P. and Perkovsky, E.: Diversity of Scydmaeninae (Coleoptera: Staphylinidae) in Upper Eocene Rovno amber, Zootaxa, 4157, 1-85, https://doi.org/10.11646/zootaxa.4157.1.1, 2016.

Jordan, K.: New Anthribidae, Nov. Zool., 31, 231-255, 1924.

Koch, C. L. and Berendt, G. C.: Die im Bernstein befindlichen Crustaceen, Myriopoden, Arachniden und Apteren der Vorwelt, in: Die in Bernstein befindlichen organischen Reste der Vorwelt, gesammelt, in Verbindung mit Mehreren bearbeitetet und herausgegeben, edited by: Berendt, G. C., Commission der Nicolaischen Buchhandlung, Berlin, Germany, 1854.

Kupryjanowicz, J., Lyubarsky, G. Y., and Perkovsky, E. E.: Heterhelus buzina sp.n. (Coleoptera: Kateretidae) from Rovno amber: the first proxy for Sambucus in the Eocene of Eastern Europe, Invertebrate Zoology, in press, 2021.

Lacordaire, J. T.: Histoire naturelle des insectes. Genera des coléopères ou exposé méthodique et critique de tous les genres proposés jusqu'ici dans cet ordre d'insectes. Tome septième contenant les familles des curculionides (suite), scolytides, brenthides, anthribides et bruchides, Librairie Roret, Paris, France, 1865 . 
Latreille, P. A.: Histoire Naturelle, Générale et Particulière, des Crustacés et des Insectes. Ouvrage faisant suite aux Oeuvres de Leclercq de Buffon, et partie du Cours complet d'Histoire naturelle rédigé par C. S. Sonnini, membre de plusieurs Sociétés Savantes. 3, Dufart, Paris, France, 1802.

Lawrence, J. F., Beutel, R. G., Leschen, R. A. B., and Ślipiński, S. A.: Glossary of Morphological Terms, in: Handbook of Zoology. Arthropoda: Insecta. Tb. 40: Coleoptera (Beetles). Vol. 2: Morphology and Systematics (Elateroidea, Bostrichformia, $\mathrm{Cu}-$ cujiformia partim), edited by: Kristensen, N. P., Beutel, R. G., Walter de Gruyter, Berlin, Germany and New York, USA, 9-20, 2010.

Legalov, A. A.: Studies upon anthribid-beetles (Coleoptera, Anthribidae) from Russia, Byulleten' Moskovskogo Obshchestva Ispytatelei Prirody Otdel Biologicheskii, 116, 21-27, 2011a.

Legalov, A. A.: First record of anthribid beetles from the Jurassic of Kazakhstan (Coleoptera: Anthribidae), Paleontol. J., 45, 629633, https://doi.org/10.1134/S0031030111060074, 2011b.

Legalov, A. A.: New curculionoid beetles (Coleoptera: Curculionoidea) from the Baltic amber, Paleontol. J., 46, 262-272, https://doi.org/10.1134/S0031030112030094, 2012.

Legalov, A. A.: New and little known weevils (Coleoptera: Curculionoidea) from the Paleogene and Neogene, Hist. Biol., 25, 59-80, https://doi.org/10.1080/08912963.2012.692681, 2013a.

Legalov, A. A.: Review of the family Anthribidae (Coleoptera) from the Jurassic of Karatau: subfamily Protoscelinae. Genus Protoscelis Medvedev, Paleontol. J., 47, 292-302, https://doi.org/10.1134/S0031030113030064, 2013b.

Legalov, A. A.: Fossil Mesozoic and Cenozoic weevils (Coleoptera, Obrienioidea, Curculionoidea), Paleontol. J., 49, 1442-1513, https://doi.org/10.1134/S0031030115130067, 2015.

Legalov, A. A.: Annotated key to weevils of the world. Part 1. Families Nemonychidae, Anthribidae, Belidae, Ithyceridae, Rhynchitidae, Brachyceridae and Brentidae, Ukr. J. Ecol., 8, 780-831, https://doi.org/10.15421/2018_280,2018a.

Legalov, A. A.: New weevils (Coleoptera, Curculionoidea) from the Eocene of the Green River, United States: Part 1, Paleontol. J., 52, 294-302, https://doi.org/10.1134/S0031030118030061, 2018 b.

Legalov, A. A.: A review of the Curculionoidea (Coleoptera) from European Eocene ambers, Geosciences, 10, 1-74, https://doi.org/10.3390/geosciences10010016, 2020a.

Legalov, A. A.: First record of a fungus weevil (Coleoptera; Anthribidae) from the Upper Cretaceous Arzamazovskaya Formation, Primorsky Krai, Russian Far East, Cret. Res., 106, 104246, https://doi.org/10.1016/j.cretres.2019.104246, 2020 b.

Legalov, A. A.: Fossil history of Curculionoidea (Coleoptera) from the Paleogene, Geosciences, 10, 1-50, https://doi.org/10.3390/geosciences10090358, 2020c.

Legalov, A. A., Nazarenko, V. Y., and Perkovsky, E. E.: A new genus of fungus weevils (Coleoptera: Anthribidae) in Rovno amber, Foss. Rec., 21, 207-212, https://doi.org/10.5194/fr-21-2072018, 2018.

Legalov, A. A., Kirejtshuk, A. G., and Nel, A.: New weevils (Coleoptera, Curculionoidea) from the earlymost Eocene Oise amber, Paleontol. J., 53, 729-751, https://doi.org/10.1134/S0031030119070049, 2019a.

Legalov, A. A., Nazarenko, V. Y., and Perkovsky, E. E.: A new species of the genus Homocloeus Jordan (Coleoptera: An- thribidae) in Miocene Mexican amber, Paleontol. J., 53, 56-61, https://doi.org/10.1134/S0031030119010040, 2019b.

Legalov, A. A., Nazarenko, V. Y., and Perkovsky, E. E.: New weevils (Coleoptera: Curculionidae) from the Rovno amber, Paleontol. J., 53, 1045-1059, https://doi.org/10.1134/S0031030119100101, 2019c.

Liang, W.-R., Wu, C.-C., and Li, H.-F.: Discovery of a cryptic termite genus, Stylotermes (Isoptera: Stylotermitidae), in Taiwan, with the description of a new species, Ann. Rev. Entomol., 110, 360-373, https://doi.org/10.1093/aesa/sax034, 2017.

Linnaeus, C.: Systema Naturae per regna tria naturae, secundum classes, ordines, genera, species, cum caracteribus, differentiis, synonymis, L. Salvii, Holmiae, Sweden, 1758.

Medvedev, L. N.: Leaf beetles of the Jurassic of the Karatau (Coleoptera, Chrysomelidae), in: Yurskie nasekomye Karatau, edited by: Rohdendorf, B. B., Nauka, Moscow, Russia, 155-165, 1968.

Morimoto, K.: The family Anthribidae of Japan (Coleoptera). Part 4, Esakia, 17, 53-107, 1981.

Nazarenko, V. Y. and Perkovsky, E. E.: A new genus and species of dryophthorid weevils (Coleoptera, Dryophthoridae: Stromboscerinae) from the Rovno amber, Paleontol. J., 43, 1097-1100, https://doi.org/10.1134/S003103010909010X, 2009.

Nazarenko, V. Y. and Perkovsky, E. E.: A new species of derelomine weevils (Coleoptera, Curculionidae, Curculioninae: Acalyptini) from the Rovno amber, Paleontol. J., 50, 991-996, https://doi.org/10.1134/S0031030116090094, 2016.

Nazarenko, V. Y., Legalov, A. A., and Perkovsky, E. E.: A new species of the genus Caulophilus Woll. (Coleoptera: Curculionidae: Cossoninae) from the Rovno amber, Paleontol. J., 45, 287290, https://doi.org/10.1134/S0031030111030105, 2011.

Perkovsky, E. E.: Rovno amber caddisflies (Insecta, Trichoptera) from different localities, with information about three new sites, Vestn. Zool., 51, 15-22, https://doi.org/10.1515/vzoo2017-0003, 2017.

Perkovsky, E. E. and Vasilenko, D. V.: Evolution of tropical termites in early Paleogene with description of a new species of Stylotermitidae (Isoptera) from Rovno amber (late Eocene of Ukraine), Inver. Zool., 17, 231-246, 2020.

Perkovsky, E. E., Rasnitsyn, A. P., Vlaskin, A. P., and Taraschuk, M. V.: A comparative analysis of the Baltic and Rovno amber arthropod faunas: representative samples, Afr. Invertebr. 48, 229-245, 2007.

Perkovsky, E. E., Zosimovich, V. Y., and Vlaskin, A. P.: Rovno Amber, in: Biodiversity of fossils in amber from the major world deposits, edited by: Penney, D., Siri Scientific Press, Manchester, UK, 116-136, 2010.

Perkovsky, E. E., Rasnitsyn, A. P., Vlaskin, A. P., and Rasnitsyn, S. P.: Contribution to the study of the structure of amber forest communities based on analysis of syninclusions in the Rovno amber (Late Eocene of Ukraine), Paleontol. J., 46, 293-301, https://doi.org/10.1134/S0031030112030136, 2012.

Petrov, A. V. and Perkovsky, E. E.: New species of bark beetles from the Rovno amber (Insecta: Coleoptera: Scolytidae), Paleontol. J., 42, 406-408, https://doi.org/10.1134/s0031030108040096, 2008.

Petrov, A. V. and Perkovsky, E. E.: A new genus and species of Scolytinae (Coleoptera: Curculionidae) 
from the Rovno amber, Paleontol. J., 52, 164-167, https://doi.org/10.1134/S0031030118020090, 2018.

Poinar Jr., G. and Legalov, A. A.: New Anthribidae (Coleoptera: Curculionoidea) in Dominican and Mexican ambers, Palaeontol. Electronica, 19, 1-38, https://doi.org/10.26879/635, 2016.

Rheinheimer, J.: Illustrierter Katalog und Bibliographie der Anthribidae der Welt (Insecta: Coleoptera), Mitt. Entomol. Ver. Stuttgart, 39, 1-288, 2004.

Scudder, S. H.: The Tertiary insects of North America, US Geol. Surv. Terr., 13, 1-734, 1890.

Scudder, S. H.: Tertiary rhynchophorus Coleoptera of the United States, Mon. US Geol. Surv., 21, 1-206, https://doi.org/10.3133/m21, 1893.

Seyfullah, L. J., Beimforde, C., Dal Corso, J., Perrichot, V., Rikkinen, J., and Schmidt, A. R.: Production and preservation of resins - past and present, Biol. Rev., 93, 1684-1714, https://doi.org/10.1111/brv.12414, 2018.
Sidorchuk, E. A. and Klimov P. B.: Redescription of the mite Glaesacarus rhombeus (Koch \& Berendt, 1854) from Baltic amber (Upper Eocene): evidence for femalecontrolled mating, J. Syst. Palaeontol., 9, 183-196 https://doi.org/10.1080/14772019.2011.566585, 2011.

Sokoloff, D. D., Ignatov, M. S., Remizowa, M. V., Nuraliev, M. S., Blagoderov, V., Garbout, A., and Perkovsky, E. E.: A male flower of Prunus s.l. (Rosaceae) from Eocene Rovno amber (Ukraine), J. Plant. Res., 131, 925-943, https://doi.org/10.1007/s10265018-1057-2, 2018.

Soriano, C., Gratshev, V. G. and Delclos, X.: New Early Cretaceous weevils (Insecta, Coleoptera, Curculionoidea) from El Montsec, Spain, Cret. Res., 27, 555-564, 2006.

Voss, E.: Einige Rhynchophoren der Bernsteinfauna (Col.), Mitt. Geol.-Paläontol. Instit. Univ. Hamburg, 22, 119-140, 1953.

Zherikhin, V. V.: On weevils (Insecta, Coleoptera) from the Baltic amber, Trudy Paleontologicheskogo Instituta, 130, 197-209, 1971.

Zherikhin, V. V.: Suborder Polyphaga, Trudy Paleontologicheskogo Instituta, 252, 20-37, 1993. 